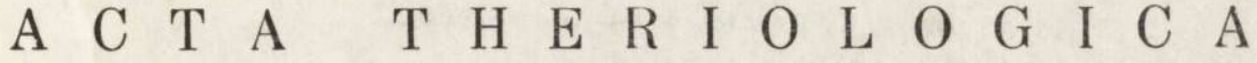 VOL. XI, 3: 55-69.

\section{Variations in the Hardness of the Teeth of Sorex araneus Linnaeus, 1758}

\author{
[With 2 Figs. \& 6 Tables]
}

\begin{abstract}
Using material consisting of 127 individuals of Sorex araneus $\mathrm{L}$ in $\mathrm{n}$ a e u s, 1758 ( 3 series from different years) it was shown by means of a micro-hardness tester that the enamel of tooth $\mathrm{I}^{2}$ varies in hardness from $260 \mathrm{~kg} / \mathrm{mm}^{2}$ to $400 \mathrm{~kg} / \mathrm{mm}^{2}$, with a mean value of $311 \mathrm{~kg} / \mathrm{mm}^{2}$. The hardness of the enamel does not alter in different years or at different seasons of the year, and is the same in both males and females. The enamel is hardest on the surface of the tooth, and softest near the dentine. Dentine varies in hardness from $44.8 \mathrm{~kg} / \mathrm{mm}^{2}$ to $90.5 \mathrm{~kg} / \mathrm{mm}^{2}$, being greatest at the borderline with the enamel at the front and back of the tooth, and least in the centre. Hardness of the dentine varies in series from different years, which has a significant effect on the rate of wear of the teeth, and hence on identification of the animals' age. There is a tendency for the dentine to be softer in individuals from the winter (older animals) than from the summer (very young animals).
\end{abstract}

\section{INTRODUCTION}

The aim of the present study was to determine variations in the hardness of the teeth of Sorex araneus. The hardness of the crowns is one of the basic factors affecting the wear of the teeth during the animal's life, and is therefore of considerable importance when the degree of wear of the teeth is used as a measure of length of life.

Up to the present time no uniform and precise system of identifying the age of animals has yet been elaborated. Numerous morphological characters, which vary to a certain degree proportionately during the indi-

* Present address: Department of Embryology, Warsaw University, Warsaw, Krakowskie Przedmieście 26/28. 
viduals's life, and which may therefore form, to a lesser or greater degree, a measure of age, are used for this purpose.

Many authors use several criteria jointly to estimate age. Among the characters frequently used for this purpose are the size of the bcdy, size of skull, degree of ossification of the skeleton, condition of the fur, sexual maturity and degree of wear of the teeth. The measurement of the weight of the eye lens (Lor d, 1959) is one of methods of age determination. This method is widely used for many species, but chiefly in relation to large animals.

The method in most general use up to the present, which permits of obtaining relatively exact data as to the animal's age, is comparison of the degree of wear of the teeth.

Many authors have used this method to determine age in relation to the genus Sorex (Stein, 1938; Hamilton, 1940; Dehnel, 1949; C onaway, 1952; Pruitt, 1954; Pucek, 1955; Rudd, 1955; Crowcroft, 1957; Popov, 1960). Each of the above authors used his own methods for determining age, generally in relation to material from one area and from a comparatively short period of time. In taking wear of the teeth as a measure of the length of life of an animal they assumed that this is most closely correlated with age in comparison with other morphological or anatomical characters. Judging by the wealth of literature on this subject, in regard not only to shrews and small rodents, but also to large game and domestic animals, it must be accepted that this is in fact the case (E i d m a n n, 1932; R a e sf eld, 1957; S o k ol ov \& R a š ek, 1961 and others). Nevertheless some doubts arise as to whether wear of the teeth does not in addition depend on certain factors not accompanying the animal throughout its life, but merely affecting the retardation or acceleration of rate of wear for a short period of time. If such factors occur, are they significant and do they cause differences between individuals from different areas or between generations from different years? The ecological side of this problem will be given more exhaustive treatment in later investigations.

Wearability is a property closely related to hardness (New burn \& Pigman, 1960 ), and is itself a complicated phenomenon from the physical aspect, dependent on many factors such as, for instance, whether wear took place "dry", or whether it was between surfaces "lubricated" in some way or another (R a b in ow i c z, 1962.) In the case of wear of teeth food plays the part of both wearing and lubricating agent. It would be extremely difficult to determine to what degree either action takes place, especially in view of the enormous variety of food eaten. Measurement of wearability has been obtained up to the present in mechanics by empirical methods and is only of any real value when strictly uniform experimental conditions

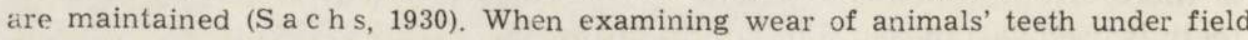
conditions this is of course impossible to achieve. More simply, wearability may be measured only by the hardness of the material examined.

There is no generally accepted definition of hardness in literature. Williams (1942) gave the following definition: "The resistance to penetration rests upon the difficulty of pushing the granules composing a body to one side and getting them out of the way of the penetrator. Hardness seems to rest upon the inter-atomic and inter-molecular forces which hold these particles together in a solid. So far as we know, these are common forces and overcoming of them is a measure of hardness". For hardness of enamel or dentine a popular definition has been given by $\mathrm{New}$ brun \& Pigman (1960), according to whom this is the capacity for constant resistance to deforming forces such as pressure and scraping. 
Using many characters of hardness as a basis, numerous instruments have been constructed to measure hardness in general, and hardness of teeth in particular. The majority of authors find that with regard to the teeth best results are obtained by measuring instruments based on the principle of resistance to penetration (Ne wbrun \& Pigman, 1960). The method of measurement consists in pressing a diamond pyramid with a base shaped like an elongated rhomb into a flat surface of a tooth under a defined load and for uniform periods and measuring the base of the impression obtained ( $\mathrm{K} \mathrm{n}$ o o p et al., 1939). The result is obtained in KHN units (Knoop Hardness Number) expressed in $\mathrm{kg} / \mathrm{mm}^{2}$, now generally accepted in measurements of the hardness of teeth. The Vickers apparatus forms a certain modification of the Knoop micro-hardness tester, differing from the prototype by reason of the square base of its diamond pyramid.

The greater part of investigations of the hardness of teeth have been carried out on human teeth, in research on methods for the prevention and treatment of caries. At the same time the influence of many factors on the hardness of teeth has been examined, but unfortunately the results of measurements made by different research workers are often contradictory, and $\mathrm{Ne}$ w br u n \& P i g m a n (1960) have discussed this in detail. It is a question here of, for instance, the hardness of enamel in females and males. There is no firmly-established opinion on the extent to which measurement of hardness of enamel or dentine depends on the place in which the measurement is made, or on the age of the individual, although as regards this latter point many authors incline to the opinion that age is of no real significance here (C a ldwell et al., 1957, Dalitz, 1962). The amount of fluorine present in the organism exerts a very strong influence on variation in the lardness of teeth. Even the action in vitro of fluorine compounds on teeth a fundamental effect on increase in the hardness of enamel and dentine (G a li ńska \& Z a lewski, 1961).

\section{MATERIAL AND METHODS}

A total of 127 shrews, collected in the Białowieża National Park hy the Mammals Research Institute at Białowieża, were used for the investigations. 50 of the individuals were from the summer (June-July) of 1953, 51 from the summer (JuneJuly) 1955 and 26 from the winter (January-February) of 1956. The specimens from 1953 and 1955 belonged to the youngest age class, identified according to the tooth standard established by Pucek (1955). The material from the winter of 1956 consisted of older animals, aged about six months.

Choice of the material for examination was made on the basis of an analysis of wear of teeth of shrews originating from a period of 14 years (1947-1961). Assuming that wear of teeth is a measure of age, it proved that old adults caught during the three spring months (March, April, May) in certain years are clearly older, and in others younger, than the shrews from the other years, the difference probably being from 3 to 4 months of life. On this account a group of animals from years deviating most extremely one way or the other from the mean wear, that is the season from $1953 / 54$ and $1955 / 56$, were taken for the investigations. One of the causes explaining the different degree of wear of the teeth in specimens which should be expected to be of very similar age may be the difference in the hardness of the teeth.

The number of old adults caught in the spring is relatively small, the degree of wear of the teeth in different individuals varying, which resulted in considerable difficulty in measuring hardness. For this reason very young specimens, aged $1-2$ months, were taken for examination. The statement made by many authors that 
hardness of teeth does not change with age, was taken as a basis in this case (C a ldwe 11 et al., 1957; Dalitz, 1962). In this connection the young specimens examined may be considered as a generation close in time of birth to the old spring individuals. The food which the mother ate during pregnancy and lactation must have been similar, as these periods are particularly important to the proper formation of teeth.

The micro-hardness tester, type PMT-3, produced in the Soviet Union in 1949 , based in principle on the Vickers apparatus, was used to measure the hardness of the tooth for 15 seconds under a loading of $50 \mathrm{~g}$. In order to facilitate measurement the second upper incisor.

The indenter of the apparatus was driven from the top into the worn surface of the tooth, which was removed from the jaw, was sunk into a plexiglass plate. The cone of the tooth was next rubbed, together with the plate, on a matt glass pane until a flat surface had been formed on the tooth with a long axis of about $450 \mu$. The worn surface of the tooth cone on which the measurement was made differed in shape from the chewing surface worn by the live animal.

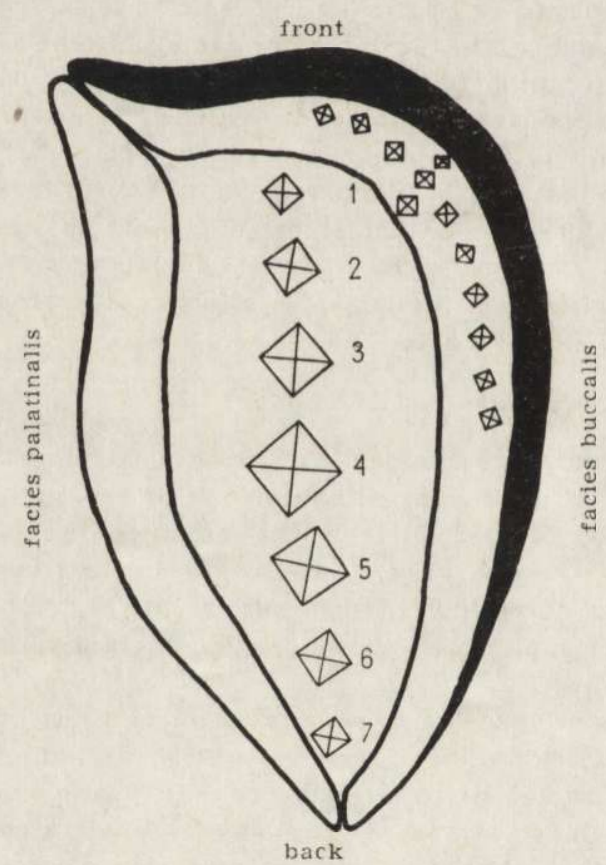

Fig. 1. Diagram of the worn surface of tooth $\mathrm{I}^{2}$ showing the places in which measurements were made (brown layer of enamel darkened).

The surface of the tooth prepared for measurements had the following appearance (Fig. 1): the external layer is formed by enamel, which consists of laminae of non-uniform thickness and length, contacting each other at their ends and surrounding the dentine. A larger lamina surrounds the tooth from facies buccalis, and a smaller from facies palatinalis. The place in which the two laminae meet is generally clearly visible, and can be particularly distinctly seen from the back of the tooth, where the rounded laminae of enamel are in contact over a very small 
section, or else there is an interval between them filled with dentine. In the anterior part of the tooth the place of contact of the two laminae of enamel was not always visible, but it was frequently quite distinct, and formed a right angle between facies palatinalis and facies buccalis of the crown. The external layer of enamel in $S$. araneus is a reddish-brown colour. The intensity of colour, thickness of the coloured layer and its length varies in different individuals. The dentine filling the centre of the tooth differs distinctly from the surrounding enamel by its slightly darker colour.

Measurements of the hardness of the enamel were started from the front of the cone of the tooth where the enamel forms the thickest layer, towards the back of the tooth, at a uniform distance from the edge of the tooth and at uniform intervals between successive impressions. Hardness was measured in the thickest place of the enamel from the surface of the tooth vertically to the dentine. Measurements of the dentine were made in a straight line along the longest diameter of worn surface of the tooth. Ten measurements of hardness of the enamel parallel to the facies buccalis were made on each tooth: three and sometimes four measurements of the enamel vertically to the surface of the tooth and on an average seven measurements on the dentine. The size of the impressions was taken from the microscope of the PMT-3 micro-hardness tester (magnification $487 \times$ ).

Measurements on a given tooth were made on one plane of wear, which was situated on all the teeth examined at an almost uniform distance from the cutting edge of the tooth. As the crown of tooth $\mathrm{I}^{2}$ is conic in shape the worn surface became larger during rubbing, and therefore the measure of distance from the apex is the dimension of the greatest diameter of worn surface, of approximately $450 \mu$. A constant level of the surface examined was adhered to in view of the possibility of variations in hardness of the tooth along its long axis. This precaution proved in fact unnecessary, since the series of measurements made on one tooth from the apex itself to the base of the cone did not reveal any differences in hardness between successive planes of measurement. Series of measurements were made in seven planes at distances of approximately $100 \mu$ from each other. In order to illustrate this mean values from measurements of hardness of enamel are given in table 1 , expressed in the diagonal size of the impression in microns in relation to the length of the worn plane of the tooth. The greatest difference occurs on the two first planes, of as much as $1.48 \mu$, while the difference does not exceed $0.38 \mu$ between further planes.

The measurements were read on the screw of the micrometer situated on the eye-piece of the microscope of the micro-hardness tester. This value was multiplied by the value of one degree of the micrometric screw in the plane of the objective equal in the given case to $0.308 \mu$ (expressed as the rounded value $0.31 \mu$ ), obtaining the diagonal length of the impression in microns. The final result was obtained in $\mathrm{kg} / \mathrm{mm}^{2}$ by reading from the table enclosed with the description of the PMT-3 microsclerometer ( $\mathrm{Chruščov} \mathrm{\&} \mathrm{Bierkovič,} \mathrm{1950)} \mathrm{for} \mathrm{the} \mathrm{given} \mathrm{load} \mathrm{and}$ diagonal length of the impression. The table only gave whole numbers of microns, while the results obtained of the diagonal length of the impression usually had tenths and hundredths. On this account the absolute values of the reading were used in all the statistic calculations to ensure greater accuracy. Hence both the diagonal length of the impression and value of hardness are given in $\mathrm{kg} / \mathrm{mm}^{2}$. 


\section{RESULTS}

Examination of hardness revealed that there are no statistically significant differences between measurements made on the enamel of one tooth $\mathrm{I}^{2}$ of $S$. araneus at a uniform distance from the external margin of the enamel (about $17 \mu$ ). Analysis of homogeneity was made by the method of coefficient of variation, which bears witness to the uniform hardness of the enamel measured in the plane vertical to the long axis of the tooth.

Table 1.

Measurement of hardness of enamel in successive planes of wear of the tooth.

\begin{tabular}{|l|r|r|r|r|r|r|r|}
\hline $\begin{array}{c}\text { Successive } \\
\text { planes of } \\
\text { measurements }\end{array}$ & I & II & III & IV & V & VI & VII \\
\hline $\begin{array}{l}\text { Length of plane } \\
\text { of the tooth } \\
\text { in microns }\end{array}$ & 339.9 & 418.8 & 454.72 & 494.2 & 498.8 & 534.0 & 631.0 \\
\hline $\begin{array}{l}\text { Diagonal of } \\
\text { indentation } \\
\text { in microns }\end{array}$ & 17.2 & 15.7 & 16.6 & 16.2 & 16,2 & 16.4 & 16.3 \\
\hline
\end{tabular}

Table 2.

Measurements of hardness across the lamina of enamel from the surface of the tooth to juncture with dentine.

\begin{tabular}{|c|c|c|c|c|c|}
\hline \multirow{2}{*}{ Year } & \multirow{2}{*}{ No. } & \multirow{2}{*}{ Unit } & \multicolumn{3}{|c|}{ Successive measurements } \\
\hline & & & 1 & 2 & 3 \\
\hline 1953 & 24 & $\begin{array}{l}\text { microns } \\
\mathrm{kg} / \mathrm{mm}^{2}\end{array}$ & $\begin{array}{l}16.8 \\
341\end{array}$ & $\begin{array}{l}18.9 \\
257\end{array}$ & $\begin{array}{c}22.3 \\
192\end{array}$ \\
\hline $\begin{array}{l}1955 \\
1956\end{array}$ & 26 & $\begin{array}{l}\text { microns } \\
\mathrm{kg} / \mathrm{mm}^{2}\end{array}$ & $\begin{array}{l}15.8 \\
362\end{array}$ & $\begin{array}{l}17.1 \\
321\end{array}$ & $\begin{array}{c}19.6 \\
232\end{array}$ \\
\hline
\end{tabular}

The value of measurement of hardness of the enamel measured transversely is differently distributed. The layer lying nearest the surface of the tooth is the hardest, while more distant ones are increasingly soft (Fig. 1). Table 2 gives the mean values of measurements of hardness made across the enamel in series of 24 young individuals from the summer and 26 older animals from the winter.

In order to establish individual variations in hardness of enamel an analysis was made of this measurement on the teeth of shrews included in the different series. The method of variance analysis was used, which 
showed that there are no differences in hardness of enamel within the series of teeth, whether from 1953, 1955, or 1956 (the mean values were verified by statistics $F$ ). The hypothesis was verified on a level of significance -0.05 . The hardness of the enamel of each tooth was described by the mean value from ten measurements made on the enamel.

No differences of hardness of the enamel was found between series of animals from 1953 and 1955 taken as a whole, either in relation to mean values or in ranges of variations (Table 3 ).

Table 3.

Ranges and mean values of hardness of enamel in different series.

\begin{tabular}{|c|c|c|c|c|c|c|}
\hline \multirow{2}{*}{ Year } & \multicolumn{2}{|c|}{ Minimum } & \multicolumn{2}{|c|}{ Maximum } & \multicolumn{2}{|c|}{ Mean } \\
\hline & $\mathrm{kg} / \mathrm{mm}^{2}$ & $\mu$ & $\mathrm{kg} / \mathrm{mm}^{2}$ & $\mu$ & $\mathrm{kg} \mathrm{mm^{2 }}$ & $\mu$ \\
\hline 1953 & 260 & 18.85 & 364 & 15.93 & 306 & 17.44 \\
\hline 1955 & 260 & 18.85 & 380 & 15.62 & 306 & 17.46 \\
\hline 1956 & 270 & 17.95 & 400 & 15.28 & 321 & 16.95 \\
\hline
\end{tabular}

Table 4.

Hardness of enamel of males and females.

\begin{tabular}{|c|c|c|c|c|}
\hline Year & No. & $\begin{array}{c}\text { Mean } \\
\text { measurement } \\
\sigma^{*} \sigma^{*}\end{array}$ & No. & $\begin{array}{c}\text { Mean } \\
\text { measurement } \\
\text { f }\end{array}$ \\
\hline 1953 & 31 & $1674 \mu$ & 19 & $17.17 \mu$ \\
\hline 1955 & 24 & $17.38 \mu$ & 22 & $17.48 \mu$ \\
\hline 1956 & 13 & $16.50 \mu$ & 11 & $16.75 \mu$ \\
\hline
\end{tabular}

In view of the meagre and contradictory information given in literature on the possible differences in the hardness of teeth of females and males, comparison was made of measurements of hardness of enamel in both sexes. From table 4 it can be seen that in none of the series examined were there significant differences between females and males. The maximum difference in mean values of the diagonal lengths of impressions occurs on 1953 and is only $0.43 \mu$.

Hardness of the dentine was examined in all the series on the teeth of 27 shrews from 1953, 24 from 1955 and 23 from 1956. Usually seven 
Table 5 .

Mean hardness of dentine from extreme (hardest) and centre (softest) points on the worn surface of the tooth.

\begin{tabular}{|c|c|c|c|c|c|c|}
\hline \multirow{2}{*}{ Year } & \multicolumn{2}{|c|}{ 1st measurement } & \multicolumn{2}{|c|}{ 7th measurement } & \multicolumn{2}{|c|}{$\begin{array}{c}\text { Centre measurement } \\
\text { (softest) }\end{array}$} \\
\hline & $\mathrm{kg} / \mathrm{mm}^{2}$ & $\mu$ & $\mathrm{kg} / \mathrm{mm}^{2}$ & $\mu$ & $\mathrm{kg} / \mathrm{mm}^{2}$ & $\mu$ \\
\hline & & & & & \multicolumn{2}{|c|}{ (5th measurement) } \\
\hline 1953 & 90.5 & 31.97 & 77.5 & 34,68 & 65.5 & 37.65 \\
\hline & & & & & \multicolumn{2}{|c|}{ (4th measurement) } \\
\hline 1955 & 81.0 & 34.73 & 78.0 & 34.53 & 51.5 & 42.73 \\
\hline & & & & & \multicolumn{2}{|c|}{ (4th measurement) } \\
\hline 1956 & 71.0 & 36.20 & 58.5 & 39.18 & 44.8 & 45.54 \\
\hline
\end{tabular}

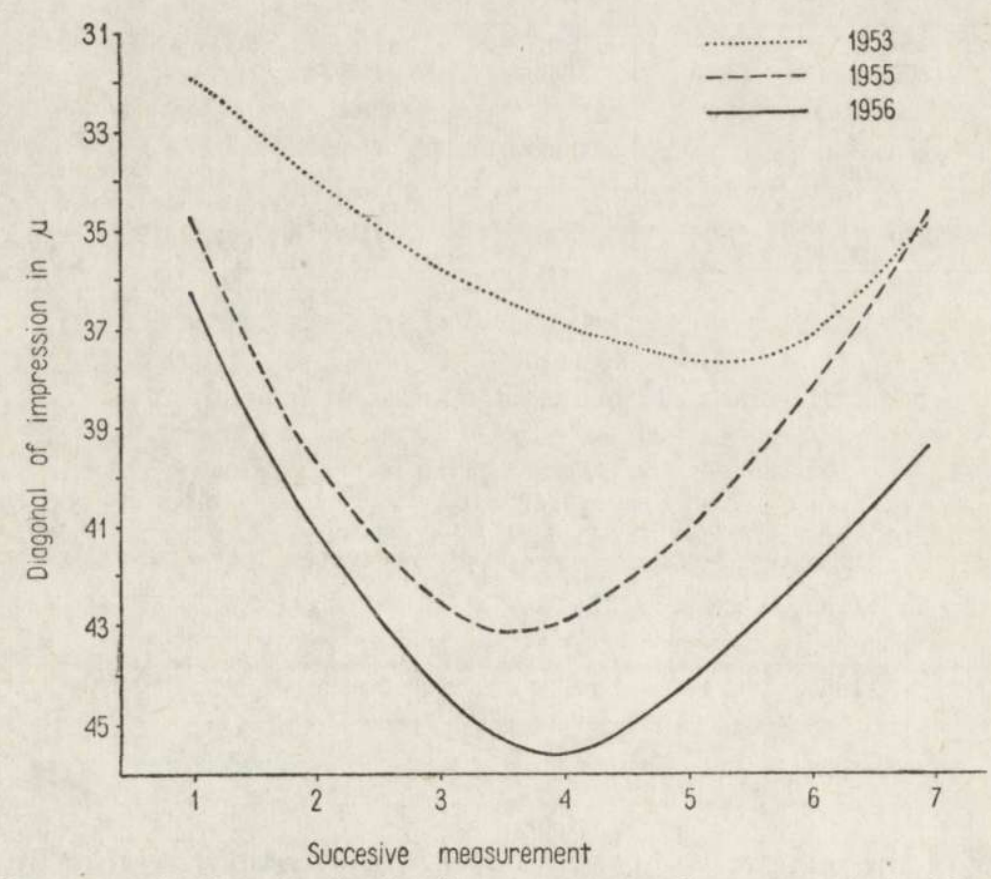

Fig. 2. Curves marked on the basis of mean values of measurenent of hardness of dentine in different series of material.

measurements were made along the greatest diameter of the worn surface of the tooth.

The measurements show that the hardness of the dentine is greatest in the place where it joins with the enamel, and least in the centre of the tooth. Variations in the hardness of the dentine in shrews exhibit a far 
smaller range than the variations in the enamel. The hardest point in the dentine of the tooth of $S$. araneus from 1953 was $90.5 \mathrm{~kg} / \mathrm{mm}^{2}(31.97 \mu$ diagonal of impression), while the softest from 1956 was $44.8 \mathrm{~kg} / \mathrm{mm}^{2}$ $(45,54 \mu)$.

Examination of the hardness of dentine showed that the series of individuals from successive years differ greatly from each other.

Data contained in Fig. 2 and table 5 show that in 1953 the young shrews had relatively hard dentine. The softest point was in the place where the fifth measurement was made. The hardness of the dentine of the teeth of young shrews from 1955 was different. The first measurement reveals far less hardness than the analogical one from 1953. The principal difference in the hardness of the dentine from the 1953 series is evident in the middle measurements (2-5), the minimum hardness occurs at the fourth measurement, while the sixth and seventh measurement do not reveal any great difference from 1953.

Table 6.

Probability of significance of differences between successive measurements of hardness of dentine in the series of teeth examined.

\begin{tabular}{|c|r|r|r|}
\hline $\begin{array}{c}\text { Series } \\
\text { Successive } \\
\text { measurement }\end{array}$ & $1953-1955$ & $1953-1956$ & $1955-1956$ \\
\hline 1 & $0.001<\mathrm{p}<0.01$ & $\mathrm{p}<0.001$ & $0.2<\mathrm{p}<0.3$ \\
2 & $\mathrm{p}<0.001$ & $\mathrm{p}<0.001$ & $0.1<\mathrm{p}<0.2$ \\
3 & $\mathrm{p}<0.001$ & $\mathrm{p}<0.001$ & $0.1<\mathrm{p}<0.2$ \\
4 & $\mathrm{p}<0.001$ & $\mathrm{p}<0.001$ & $0.02<\mathrm{p}<0.05$ \\
5 & $0.001<\mathrm{p}<0.01$ & $\mathrm{p}<0.001$ & $0.001<\mathrm{p}<0.01$ \\
6 & $0.3<\mathrm{p}<0.4$ & $\mathrm{p}<0.001$ & $0.001<\mathrm{p}<0.01$ \\
7 & $0.8<\mathrm{p}<0.9$ & $\mathrm{p}<0.001$ & $\mathrm{p}<0.001$ \\
\hline
\end{tabular}

Shrews from 1956 form a series of older animals than the individuals from the series previously described. They exhibit the least hardness of dentine along the whole axis of measurements. The softest point is at the fourth measurement, as it was in the 1955 series.

Comparison was made between 1953-1955, 1953-1956, and 1955-1956 for successive measurements of the hardness of dentine. Analysis was made by means of the $t-S t u d$ en t statistics with $\left(n_{1}+n_{2}-2\right)$ degrees of freedom, where $\mathrm{n}_{1}$ is the number of samples in one year, correspondingly $\mathrm{n}_{2}$ in the second year. The results of the analysis are given in table 6 . Assuming the level of significance to be $\alpha=0.05$ we reach the following conclusions: 1) when comparing series from 1953 with those of 1955 the differences are significant with the exception of the sixth and seventh 
measurement, 2) the series from 1953 differs significantly from the series from 1956, 3) Comparison of series from 1955 and 1956 gives significant differences only for the fifth, sixth and seventh measurement.

The results of statistical calculations and Fig. 2 show that the difference in hardness of the dentine between the series from 1953 and from 1955 is significant to a very high degree. The absence of this difference in the final two measurements may be attributed to the approach to the enamel, in the vicinity of which the dentine is harder and may be subject to smaller fluctuations in relation to the central part. The second cause may be an error made during measurements, that is, the posterior part of the crown forms an acute angle (Fig. 1) and on this account the distance of the central line of the dentine from the enamel is smaller. In effect a minimum shift of the place of pressure to the right or left produces a result of greater hardness, since it is nearer the enamel. This might affect the results of the two final measurements of the dentine in the series from 1955. The low degree of hardness in the sixth measurement of the 1953 series may be explained either by the inclination of the neighbouring measurements in the direction of the enamel, which would produce a strong contrast between these measurements, or by a relatively considerable shift of the sixth measurement toward the centre. It is also possible that this phenomenon is due to yet other causes.

The series of shrews from 1956 exhibit the least hardness of dentine of tooth $\mathrm{I}^{2}$. It differs significantly over the whole surface from 1953 series. In relation to 1955 the differences are significant only in half the measurements, although the remaining ones also exhibit a tendency to lesser hardness than the dentine in the 1955 series. Of course it is possible here also to consider whether the final measurements are not burdened by error due to the technique of measurement itself. It might, for instance, be assumed that the apparently lesser hardness of the dentine from the posterior part of the tooth is due to the way the teeth were worn by the animal itself. As has already been mentioned this series consisted of older individuals, in which the degree of wear of the teeth is sufficiently great for the plane of wear, during preparation for measurements, to incline slightly towards the back of the tooth and to run through the deeper, and therefore less hard, layers of dentine lying close to the pulp.

\section{DISCUSSION}

Wear of the teeth is of exceptionally great importance in determining the age of animals, and therefore any differences which can be observed between the degree of wear in individuals of very similar age, but from 
different years, have a significant influence on the degree to which the estimate of age based on this criterion is objective ${ }^{1}$ ).

In the case of $S$. araneus the differences in the wear of the teeth in old adults from March and April 1954 and 1956 indicate that these series differ from each other by almost 4 months of life. In view of the fact that the life span of shrews in the area is not longer than one year, this error would constitute $1 / 3$ of the life span ${ }^{2}$ ).

Comparison of the two series described is particularly striking on account of the choice of years with extreme differences, yet the differences between other years may vary within limits of $2-3$ months.

In considering the application of degree of wear of the teeth to determination of the age of animals it is a question of finding a time factor which exerts a uniform and even influence. As can be seen from the arguments presented above the factor of hardness of the teeth, which has an either strengthening or weakening action on the effect of wear, must also be taken into consideration. This is of particular importance where material originating from a large number of years is being used, and which may differ as distinctly as that of the example of $S$. araneus given in this study.

The majority of authors find that the hardness of enamel measured on the cross-section of the tooth is from 160 to $300 \mathrm{KHN}$. The most recent examination of the hardness of the external surface of the enamel gives a hardness value from 300 to $400 \mathrm{KHN}$ (all data after $\mathrm{Newbrun}$ \& $\mathrm{P}$ ig m a n, 1960). These data are very similar to the results obtained for S. araneus, which vary from 260 to $400 \mathrm{~kg} / \mathrm{mm}^{2}$. It must be remembered that the measurements in this study were made with the PMT-3 apparatus, which might produce certain differences in results.

Measurements of the hardness of enamel made across the lamina, showing that hardness decreases in a direction from the surface of the enamel to its juncture with dentine, are in agreement with results cbtained by very many authors cited by Newbrun \& Pigman (1960). It must be added that the lamina of enamel situated most externally, containing the brown colour, crushed very easily even when grinding the tooth and during the actual measurement. These measurements were not taken into consideration.

The material examined did not reveal significant differences in the hardness of enamel in male and female shrews. This agrees with the opinion held by Proell \& Schubert (1928), but not with that of

1) This perhaps applies to different areas also, where on account of the differences in the mineral composition of the soil, and therefore different salts contents in nutrient components, the structure of the teeth and their hardness are effected.

$\left.{ }^{2}\right)$ Calculation was made on the basis of a standard tooth age from marked shrews. 
$\mathrm{K} u \mathrm{hn}$ (1895) who considered that enamel is harder in females than in males. As N ewbrun \& Pigman (1960) state, this problem has still not been thoroughly examined and is therefore unsolved.

Both enamel and dentine participate in the wear of the teeth. The data given above show that the hardness of the enamel is not subject to fluctuations or changes. The hardness of dentine, on the other hand, is different, and is, as it were, more sensitive to changes with age, season etc. It proved that the layer of enamel, far harder than the dentine, cannot maintain the rate of wear independently of the dentine, the suriace of which, as the tooth becomes worn, becomes larger and imposes its own rate of wear. It is therefore obvious that the differences in wear of the teeth may be due to variations in the hardness of the dentine itself, without the participation of the enamel.

The cause of the differences in the hardness of dentine in different years is not clear, neither has it yet been established to what degree this character is correlated with the other morphological and physiological characters of this species. The differences demonstrated here in the hardness of dentine between series of young individuals from the summer and older individuals caught in the winter, lead to two assumptions. In the first place, that there is a difference between old and young individuals in the direction of decrease in the hardness of dentine over the lifespan. This opposed to the views held by Dalitz (1962) who maintains that the hardness of dentine is not subject to changes with age. In the second place there is the possibility of connecting these facts with $\mathrm{D}$ e h n e l's phenomenon, that is, the winter depression of the skull linked with depression in weight and body size (D e h n e l, 1949). Unfortunately the cause of the seasonal variations in shrews is unknown and it is therefore difficult to form an opinion as to whether the reduction in hardness of dentine in winter specimens has the same physiological foundation. It is clear that further and more detailed research on more extensive material is called for. The final explanation of this problem might form an interesting contribution to the phenomenon of winter depression in shrews.

When considering wear of the teeth as a diagnostic character in estimating age it is necessary to draw attention to certain factors which probably, in addition to hardness, to a certain extent influence the effect of wear. The composition of the food accessible to the animal over a long period of its life is amongst the basic factors. Another factor is the wear of teeth on each other, which has so much smaller influence on differences in the degree of wear of teeth in a population that the differences occurring here are of the character of individual variability. This is connected with the type of bite, and therefore the direction in which the 
chewing plane of the crown is worn. Both of these two factors require investigation under laboratory conditions.

In summing up the results of the present investigations it may be said that the hardness of dentine is subject to significant variations in different years and causes differences in the rate of wear of the teeth of $S$. araneus, which in practice makes it necessary to correct the estimate of age on the basis of the wear of the teeth.

Acknowledgments: I should to express my grateful thanks to Anna Szy m a ń$\mathrm{sik}$ a, M. Sc, head of the Materia Medica Laboratory of the Drug Institute in Warsaw for giving me access to the apparatus for measuring the hardness of teeth, and to Witold $\mathrm{Z}$ a lewski, M. Sc, and Dr. Wiesław Koby lecki for their help and valuable advice during the actual measuring work. I am also most grateful to Teresa Wierzbowska, M. Sc, of the Institute of Ecology, Polish Academy of Sciences, for her statistical elaboration of the material.

\section{REFERENCES}

1. Caldwell R. C., Muntz M. L., Gilmore R. W. \& Pigman W., 1957: Microhardness studies of intact surface enamel. J. D. Res., 36: 732-738.

2. Chruščov M. M. \& Bierkovič E. S., 1950: Pribory PMT-2 i PMT-3 dla ispytania na mikrotwierdnost. Ak. Nauk SSSR. Moskwa.

3. Con a w a C. H., 1952: Life history of the Water Shrew (Sorex palustris navigator J a c k s o n, 1928). Am. Midl. Nat., 48, 1: 219-248.

4. Crowcroft P., 1957: The life of the shrew. Max Reinhardt. 1-166, London.

5. Dalitz G. D., 1962: Hardness of dentin related to age. Austral. Dent. J., 7: 463-464.

6. D e hn e 1 A., 1949: Badania nad rodzajem Sorex L. Ann. Univ. M. Curie-Skłodowska, C 4, 2: 17-102.

7. Eidmann H., 1932: Alterserscheinungen am Gebis des Rothirsches. Mittlg. Forstwirtsch. u Forstwissen., 2.

8. Galińska J. \& Z a lewski W., 1961: Twardość tkanek zẹba w zależności od stężenia i czasu przebywania w roztworach NaF. Czas. Stomat. 14: 157-163.

9. Hamilton W. J., 1940: The biology of the Smoky Shrew (Sorex fumeus fumeus M ille r). Zoologica 25, 1-34: 472-495.

10. Knoop F., Peters G. C., \& Emerson W. B., 1939: A sensitive pyramidal diamond tool for indentation measurments. J. Res. Nat. Bur. Stds., 23: 39-61, (cited after Newbrun \& Pigman, 1960).

11. Kuhns C., 1895: Untersuchungen über die chemische Zusammansetzung der harten Zahnsubstanzen des Menschen in verschiedenen Altersstufen. Inaug. Diss. Leipzig. (cited after Newbrun \& Pigman, 1960).

12. Lord R. D., Jr., 1959: The lens as an indicator of age in cottontail rabbits. J. Wildl. Mgmt., 23, 3: 358-360.

13. Newbrun E. \& Pigman W., 1960: The hardness of enamel and dentine Austral. Dent. J., 5, 4: 210-217.

14. P o p o v W. A., 1960: Mlekopitajuščie Volžko-Kamskovo kraja. Ak. Nauk SSSR. 1-468. Kazan'.

15. Proel1 \& Schubert, 1928: Die Ritzharte des Schmelzes. Ztschr. Stomatol., 26: 1047-1063 (cited after N e w br un \& P i g m a n, 1960). 
16. Pruit W. O., 1954: Ageing in the masked shrew, Sorex cinereus cinereus K e r r. J. Mammal., 35, 1: 35-39.

17. Pucek Z., 1955: Untersuchungen über die Veränderlichkeit des Schädels im Lebenszyklus von Sorex araneus araneus L. Ann. Univ. M. Curie-Skłodowska, C 9, 4: 163-211. Lublin.

18. R a b in ow ic z E., 1962: Wear. Sci. American. February: 127.

19. R a e s f eld F. v., 1957: Das Rotwild. Verlag Paul Parey, 1-385. Hamburg Berlin.

20. R u d d R. L., 1955: Age, sex and weight comparisons in three species of shrew J. Mammal., 36, 3: 323-339.

21. S a c h s G., 1930: Handbuch der Experimental Physik. 5. Plastische Vervarmung. Wien-Harms: $1-466$. Leipzig.

22. S ok olov I. I. \& R a šek W. L., 1961: Razvite zubov i čerepa kak pokazatiel vozrasta u sajgi, Saiga tatarica L. Biul. Mosk. O-va Ispyt. Prirody, Otd. biol. 66, 6: 77-98.

23. S t e i n G. H. W., 1938: Biologische Studien an deutschen Kleinsäugern. Arch. f. Naturgesch. N. F., 7, 4: 477-513. Leipzig.

24. Will i a m s S. R., 1942: Hardness and hardness measurements. Am. Soc. Metals. Clevland, Ohio. (cited after Newbrun \& Pigman, 1960).

Received July 15, 1965.

Polish Academy of Sciences, Mammals Research Institute, Białowieża, woj. Białystok. and

Department of Embryology,

Warsaw University,

Warsaw, Krak.-Przedmieście 26/28.

\section{Krystyna A. ADAMCZEWSKA-ANDRZEJEWSKA}

\section{ZMIENNOSĆ TWARDOSCI ZĘBOWW SOREX ARANEUS L I N N A E U S, 1758}

\section{Streszczenie}

Do badań użyto siekaczy $\left(\mathrm{I}^{2}\right) 127$ okazów ryjówki aksamitnej (Sorex araneus L inn a e u s, 1758) zebranych przez Zakład Badania Ssaków PAN w Białowieży na terenie Białowieskiego Parku Narodowego. Materiał zostal opracowany w trzech seriach: 50 okazów z czerwca i lipca 1953 roku, 51 okazów z czerwca i lipca 1955 roku i 26 okazów ze stycznia i lutego 1956 roku. Pomiarów twardości dokonywano mikrotwardościomierzem PMT-3 na plasko zeszlifowanej żującej powierzchni korony. Wykonywano 10 pomiarów na szkliwie wzdłuż policzkowej płaszczyzny zęba, 3 pomiary w poprzek listwy szkliwa i przeważnie $7 \mathrm{w}$ środkowej linii pola dentyny (Ryc. 1).

Stwierdzono, że twardość szkliwa zęba I $S$. araneus waha się w granicach od $260 \mathrm{~kg} / \mathrm{mm}^{2}$ do $400 \mathrm{~kg} / \mathrm{mm}^{2}$, twardość dentyny od $44,8 \mathrm{~kg} / \mathrm{mm}^{2}$ w środkowych partiach zęba do $90,5 \mathrm{~kg} / \mathrm{mm}^{2}$ w pobliżu szkliwa. Szkliwo jednego zęba mierzone wzdłuż powierzchni policzkowej jest jednorodne pod względem twardości. Szkliwo jest najtwardsze od strony powierzchni, najbardziej miękkie w miejscu połączenia z zębiną.

Nie ma różnic $\mathrm{w}$ twardości szkliwa $\mathrm{w}$ obrębie serii z poszczególnych lat, między seriami z 1953 i 1955 roku (Tab. 3), ani między samcami i samicami (Tab. 4).

Dentyna jest najtwardsza w pobliżu szkliwa, najbardziej miękka w środku plaszczyzny starcia (Ryc. 1 i 2). Miẹdzy seriami z lat 1953, 1955 i 1956 występuje różnica 
twardości dentyny istotna statystycznie we wszystkich lub w części pomiarów (Tab. 5, 6). Różnice twardości dentyny u csobników z lat 1953 i 1955 o podobnym wieku, wpływają na obiektywność oceny wieku na podstawie starcia zębów.

Serie z lata 1955 i zimy 1956 roku różnią się istotnie w trzech pomiarach. Swiadczy to o tendencji do zmniejszania się twardości dentyny z wiekiem lub porą roku (Tab. 5, Ryc. 2).

Szybkość ścierania zẹbów jest zależna od ich twardości, przy czym różnica w twardości dentyny powoduje zmiany tempa ścierania zẹba bez wzglẹdu na niezmieniającą się twardość szkliwa. 